\title{
1 \\ Manning Clark and Peter Ryan
}

Peter Ryan cried out in the dark,

'My greatest success was M. Clark

An odd sort of chap

Whose writings were crap;

I published them just for a lark.'

Chris Wallace-Crabbe ${ }^{1}$

During their 25-year professional relationship, from 1962 until 1987, Manning Clark was Australia's best-known and most controversial historian, and Peter Ryan probably became Australia's best-known publisher and certainly the best-known academic publisher.

Clark's career trajectory, like his life itself, was singular, even if he was by no means unusual among Australian historians in being a clergyman's son. His father was Charles Clark (1881-1951) an Anglican Church minister of low-church persuasion who, in the parlance of the time, had aspired above his station in marrying Catherine Hope (1878-1943), of distinctly upper-middle-class background and a descendant of Rev. Samuel Marsden. Clark and his two siblings were born in Sydney, but their father's adultery resulted in the family being shuffled to a vicarage at Phillip Island, near Melbourne. Manning Clark regarded his two years on

1 Handwritten copy of untitled limerick in the Macintyre Papers, National Library of Australia (hereafter NLA), MS 9389, Series 1, Box 5, Folder 32 (published with the poet's permission). 
the island, when he was between the ages of seven and nine, as the idyllic part of his life that licensed him in later years to describe himself as 'a boy from the bush', when in fact he was a thoroughgoing urbanite. ${ }^{2}$

Much of the information about Clark's early years comes from his autobiography of childhood and coming of age (The Puzzles of Childhood), which he wrote in his old age. ${ }^{3}$ Puzzles is more revealing of Clark the historian than an accurate depiction of the events and relationships described. His brother and sister were scandalised by the book, considering it a travesty of their family life. ${ }^{4}$ As Clark's latest biographer puts it:

His parents appear in Puzzles either as characters playing out his own inner conflicts or as mere precursors of his later self ... In Puzzles, Clark dramatized his parents' relationship, imagined his way into their minds and hearts, spoke for them and through them, invented thoughts and conversations, and recreated the experience of his early family life as a tragedy. The boy's world was inhabited by two types of human beings: angels and devils. His memories behaved with uncanny poetic licence ... or they conveniently served to explain what the old man had become ('my mother tells me one day I will be a famous man'). The whole narrative was infused with a moody, eternal melancholy ... descending on the reader like a heavy fog. ${ }^{5}$

In this, perhaps, we can discern Clark's tendency in the History to base his narratives around a series of personality clashes.

Charles and Catherine did not have a particularly happy marriage but the temptation to see the siblings as being overly defensive is dispelled when one realises that contemporaries at the prestigious Melbourne Grammar School, where Clark was enrolled in 1928, considered that the allegations in Puzzles of bullying were greatly exaggerated and that the book misrepresents the culture of the school beyond recognition. ${ }^{6}$ Being an accomplished cricketer and a precocious student eased his

2 Stephen Holt, A Short History of Manning Clark, Sydney: Allen \& Unwin, 1999, p. 9.

3 Manning Clark, The Puzzles of Childhood, Melbourne: Viking, 1989; republished by Penguin Books Australia, 1990.

4 Peter Ryan interviewed by John Farquarson, 10-11 October 2000 (p. 37 of transcript), NLA, ORAL TRC 4631; Ryan, notes of telephone conversation with A.G.L. Shaw, 4 October 1993, Ryan Papers, NLA, MS 9897, Series 6, Box 10, Folder 4; Mark McKenna, An Eye for Eternity: The Life of Manning Clark, Melbourne: Miegunyah Press, 2011, p. 61.

5 McKenna, An Eye for Eternity, pp. 59-60.

6 Brian Matthews, Manning Clark: A Life, Sydney: Allen \& Unwin, 2008, p. 17; McKenna, An Eye for Eternity, pp. 93, 721 n.3. 
path; he was dux equal in 1933. Rather than being a reliable account of his earlier life, Puzzles opens a window on the historian that Clark had become-prone to distortion, needing to be noticed and striving for effect, with his spiritual musings and ethereal turns of phrase imparting an aura of profundity.

Academic success followed him to the University of Melbourne where he caught the eye of the recently appointed professor of history, R.M. (Max) Crawford (1906-1991). At that time the usual high road to success was a scholarship to Oxbridge to complete a second degree, and Clark was the first of Crawford's bright young men to be sent to Oxford University (usually to Balliol College where Crawford himself had studied). ${ }^{7}$ Clark sallied forth to Balliol in 1938, accompanied by his fiancée, Dymphna Lodewyckx (1916-2000), an accomplished linguist, who was set for postgraduate study of her own in Germany. With World War II in progress, Clark (by then married to Dymphna) insisted on their returning to Australia, in 1940, despite their studies being incomplete. Unable to secure a university job, he spent a frustrating four years teaching at Geelong Grammar School and trying to write up an MA thesis on Alexis de Tocqueville on the side. ${ }^{8}$ Salvation came in 1944 with a temporary lectureship in political science at the University of Melbourne, and the following year he secured a permanent position in the department of history. He was doubly fortunate in being able to teach a full-year course in Australian history, which his students, Peter Ryan included, recall with yearning: 'The man could teach as naturally as a thrush could sing', was Ryan's verdict.' Clark liked to think that 'the historical map of Australia', when he started teaching at the University of Melbourne, 'was almost a blank' and that he 'had to set out on a journey without

7 Fay Anderson, An Historian's Life: Max Crawford and the Politics of Academic Freedom, Melbourne; Melbourne University Press (hereafter MUP), 2005, pp. 226-27; John Poynter, “Wot Larks To Be Abroad": The History Department, 1937-71', in Fay Anderson and Stuart Macintyre (eds), The Life of the Past: The Discipline of History at the University of Melbourne, 1855-2005, Melbourne: Department of History, University of Melbourne, 2006, pp. 39-91, specifically pp. 57-59.

8 Posthumously published as Manning Clark, The Ideal of Alexis de Tocqueville, ed. Dymphna Clark, David Headon and John Williams, Melbourne: MUP, 2000.

9 Peter Ryan, 'Manning Clark', in his Lines of Fire:Manning Clark \& Other Writings, ed. A.K. Macdougall, Binalong, NSW: Clarion Editions, 1997, pp. 179-214, specifically p. 185. Other memories are recalled in John Thompson, The Patrician and the Bloke: Geoffrey Serle and the Making of Australian History, Canberra: Pandanus Books, 2006, pp. 134-37; Geoffrey Blainey, Before I Forget: An Early Memoir, Melbourne: Hamish Hamilton, 2019, pp. 154-56; Hugh Stretton to Clark, 7 August 1987, Manning Clark Papers, NLA, MS 7550, Series 18, Box 158, Folder 27. 
maps.$^{10}$ A little earlier, in 1938 , he went so far as to say that Australian history had been 'betrayed' by its practitioners. ${ }^{11} \mathrm{He}$ was doing less than justice to his predecessors. Rather, he stood on their shoulders and they provided fodder for his earlier lectures. That the secondary literature was not extensive had the indirect advantage of Clark requiring his honours students to engage in archival research.

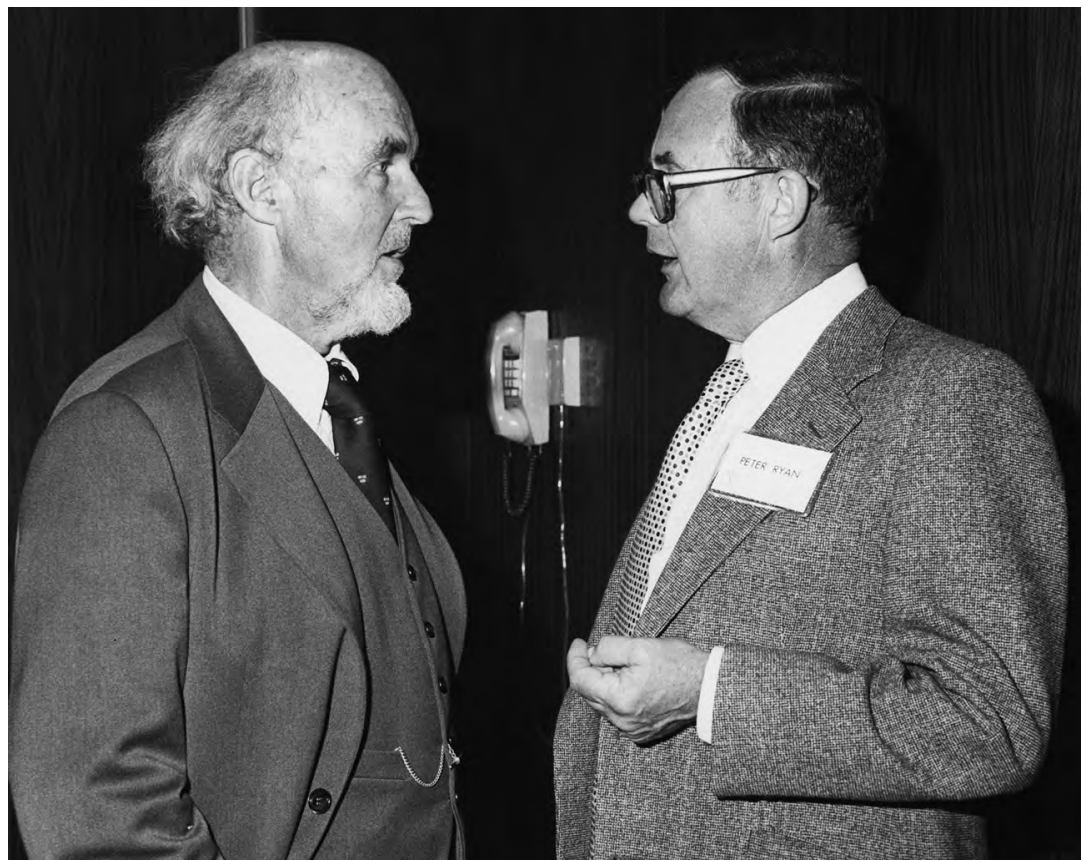

Figure 3. In happier times. Peter Ryan and Manning Clark at the National Press Club, Canberra, 17 April 1980.

Source. University of Melbourne Archives, 1993.0063.00001. Reproduced with permission.

Such was the state of the academic job market that Clark was appointed, in 1949, professor of history at Canberra University College, a satellite of the University of Melbourne. He would not have secured a lectureship when judged by today's standards-no $\mathrm{PhD}$, no academic publications and the first volume of Select Documents in Australian History (1950) still

10 Quoted in McKenna, An Eye for Eternity, p. 250. Actually, the first such course in Australian history was mounted 20 years earlier, at the University of Melbourne no less. See Stuart Macintyre, A History for a Nation: Ernest Scott and the Making of Australian History, Melbourne: MUP, 1994, p. 103.

11 McKenna, An Eye for Eternity, p. 145. 
with the publisher. He and Dymphna would spend the rest of their lives in the nation's capital, and from that base he wrote his epic six-volume A History of Australia.

Clark's great ambition was 'to tell Australia's story', but without being constrained by the canons of an increasingly professionalised, universitybased discipline. Telling Australia's story was a major commitment, whose rationale and journey are beautifully delineated by Monash University historian John Rickard:

Manning Clark, Patrick White and Sidney Nolan belong to a generation that, growing up in the shadow of cultural dependency, felt a burning need to imagine myths and monuments. So White despatched 'Voss' on his spiritual journey ('I am compelled into this country'), while Nolan transformed a bushranger into a surreal symbol of the landscape. Clark, who pioneered the teaching of Australian history, chose nothing less than to write the whole story' of his country, a history that 'was going to tell the reader something about life'.

He first put pen to paper in 1956 - the time of the Melbourne Olympics, the birth of 'Quadrant' and the debut of Edna Everage. The setting was ironically_yet perhaps appropriately_Oxford, for the telling of this story was in a sense the voyage of 'an Austral Briton' from the Old World to the New. Although he knew some of 'the great themes' he wanted to proclaim, the shape of the whole 'History' remained problematic and he was uncertain where it might end. It became part of his life, and its character and import changed as Clark himself underwent a transformation from history professor to cultural statesman. The sixth and last volume, published in 1987, ground to a halt in 1935, a time when Clark had been a student at Melbourne University. It might have been poetic symmetry to have brought it up to 1956 , to that very moment when he wrote the first sentence: 'Civilisation did not begin in Australia until the last quarter of the eighteenth century'. ${ }^{12}$

12 John Rickard, 'Manning abridged', Age Weekend Supplement, 13 November 1993, p. 8. 
Far from being in the thrall of Rankean scholarship, Clark aspired to write grand narrative history in the manner of the nineteenth-century masters and in a way, moreover, that would reflect glory upon himself. As early as 1938, at a mere 23 years of age, he told Dymphna that he felt certain that he could 'write something some day on Australian history' and that he would approach the task with insight and originality. He went on to say:

I believe quite passionately that Australia is a 'weird' country and that its weirdness has never been portrayed before except in landscape painting. Australia is virgin soil in this respect \& I feel something can be done about it. ${ }^{13}$

Full marks for the audacious ambition to supersede what had gone before and a vision of how to go about it. But his reasoning at another level might have set alarm bells ringing when he confided to his notebooks, in 1943:

The confession must be made, my motive is to impress, vulgarly, to play to the gallery. It will satisfy my ego to produce a work which will bring publicity to me. ${ }^{14}$

Historian Carl Bridge nicely captures how this aspiration, and its accompanying clichés and pat phrases, worked in practice:

Clark wrote his books in a language taken from the Bible, the Book of Common Prayer, and bits of Ibsen, Carlyle, Gibbon, Tolstoy, Newman, Marx, Macaulay, Dickens, Hardy, Henry James, Lawson and, above all, Dostoevsky-'I want to be there when everyone suddenly understands what it has all been for'. This is apocalyptic stuff. A search for divine truths and flaws in the clay. All humanity is divide[d] up into suffering virgins, Magdalens, forgiving Christs, 'banquet of life' men, and 'measurers', 'straighteners' or 'men in black coats'. He invented or stole a whole quasi-mythical terminology to describe his Australia-for instance, bourgeois society is 'Yarraside' or 'the six-toed sloth of British philistinism'; the Australian republic is the 'Young Tree Green' and the British Empire is the 'Old Dead Tree'. Is this history or is it myth?'

13 Quoted in McKenna, An Eye for Eternity, pp. 145-46.

14 Quoted in McKenna, An Eye for Eternity, p. 221.

15 Carl Bridge, 'Manning Clark and the Ratbag Tradition', Journal of Australian Studies, vol. 21, nos 54-55, 1997, pp. 91-95, specifically p. 92, doi.org/10.1080/14443059709387341. 
Clark, in other words, mirrored the great nineteenth-century historians by writing character-driven narratives on an epic canvas, not according to 'scientific' precepts of the discipline but rather in the literary tradition of Gibbon and Carlyle. They, in turn, were criticised by their contemporary J.R. Seeley for turning history into a 'department of belles-lettres' that had scant regard for the truth-a charge that would be applied to Clark by some of his own contemporaries. ${ }^{16}$

In short, Clark was a throwback from a previous age; the one difference was that the romantic idealisation of heroes was not part of his repertoire. Academically he was a generalist in an age of increasing specialisation, writing history on an expansive canvas, increasingly doing so for a public rather than an academic audience. In fact, he wrote only two journal articles involving original research. ${ }^{17}$ Aesthetically, Clark saw history as a branch of literature and, as preparation and inspiration for each volume of the History, he steeped himself in the literary classics-above all those of the Russian novelist Fyodor Dostoevsky (1821-1888)—and the historians of classical antiquity, as well as in classical music and the landscape. ${ }^{18}$ Politically, and again like many of the nineteenth-century English and American historians, he cast himself in the role of public moralist, claiming 'the right to judge [his] society as a whole and to prescribe the best way of resolving its most perplexing dilemmas and conflicts'. ${ }^{19}$

University of Sydney historian Hazel King (1908-1997) favourably summed up Clark's intentions, at the same time gently indicating some of its pitfalls and limitations:

16 Deborah Wormell, Sir John Seeley and the Uses of History, Cambridge: Cambridge University Press, 1980, p. 126.

17 M. Clark, 'The Origins of the Convicts Transported to Eastern Australia, 1787-1852: Part I', Historical Studies, Australia and New Zealand, vol. 7, no. 26, 1956, pp. 121-35, doi.org/10.1080/ 10314615608595051; Clark, 'The Origins of the Convicts Transported to Eastern Australia, 17871852: Part II', Historical Studies, Australia and New Zealand, vol. 7, no. 27, 1956, pp. 314-27, doi.org/ 10.1080/10314615608595070; Clark, 'The Choice of Botany Bay', Historical Studies, Australia and New Zealand, vol. 9, no. 35, 1960, pp. 221-32, doi.org/10.1080/10314616008595173.

18 Manning Clark, A Historian's Apprenticeship, Melbourne: MUP, 1992, pp. 77-79.

19 Wormell, Sir John Seeley and the Uses of History, p. 179; see also Sean R. Busick, A Sober Desire for History: William Gilmore Simms as Historian, Columbia: University of South Carolina Press, 2005, pp. 18-19. The literary and intellectual influences bearing on Clark are discussed by his daughter Katerina Clark, 'Manning Clark and Russia: A Memoir', in Stuart Macintyre and Sheila Fitzpatrick (eds), Against the Grain: Brian Fitzpatrick and Manning Clark in Australian History and Politics, Melbourne: MUP, 2007, pp. 258-70. 
For those who, like Bury, believe that history is 'a science, no more and no less', Professor Clark's History of Australia will have no appeal for it is above all literary history, a work of art rather than of science. But those who believe that there is not one way but many ways by which historians can lead us to a better understanding of the past, will acclaim it. For as the artist makes us aware of a world which we had looked at, but never before seen, so Professor Clark, with his highly individual vision, illumines areas of the past which before were obscure. It does not, of course, follow from this that we will agree with all that he shows us, any more than we may be wholly in sympathy with the vision of the artist. But both have deepened our understanding ...

... But while we may not agree with all that Professor Clark has to say, and while a few inaccuracies and omissions could be pointed to, his book remains a tour de force, a great achievement. It is not, nor does it claim to be, 'the' history of Australia, but rather 'a' history of Australia - a personal view of our past as seen by a discerning and perceptive historian. It cannot fail to contribute much to our understanding of the period with which it deals. ${ }^{20}$

The singular writer was matched by an equally singular personality. A controversial and often polarising figure, Clark was inspiring to some and infuriating to others. His ability to ruffle feathers was legend. In a moment of real frustration, Max Crawford made the observation that 'there is a lot to be said for plain blokes who have never read a line of Dostoyevsky. ${ }^{21}$ It is little wonder, during the paranoia of the Cold War years, that he was widely regarded as a 'closet red' and attracted unfriendly attention from ASIO (the Australian Security Intelligence Organisation). Given his own experiences and of others whom he knew about, Clark was untoward in reminiscing that people blamed ASIO for 'their failure to be appointed to positions to which they believed their talents and their industry entitled them' rather than acknowledging their

20 Hazel King, review of Volume 2 (1822-1838), Journal of Religious History, vol. 5, no. 2, 1968, pp. 180-82, doi.org/10.1111/j.1467-9809.1968.tb00502.x. King was an authority of the history of early colonial New South Wales. She wrote biographies of Governor Richard Bourke and Elizabeth Macarthur, and became the first female President of the Council of the Royal Australian Historical Society, 1982-85.

21 Quoted in Anderson, An Historian's Life, p. 283. 
own deficiencies. ${ }^{22}$ In reality, ASIO's harassment and incursions into academic freedom were pervasive, including Clark's house being put under observation..$^{23}$ Moreover, Australian universities were disinclined to confront the organisation in defence of their own staff members. ${ }^{24}$

The other protagonist in this story, Peter Ryan, was close to the mark in observing:

through most of his life, Manning's politics kept him in and out of hot water; he made sure of this, because although some of the resultant controversies were painful and distracting from his work, he found the lure of the accompanying publicity irresistible. ${ }^{25}$

Through his writing and his utterances, Clark had always had a public profile and one that became overtly political. He had what has been described as 'an unsurpassed talent for getting up right wing nostrils', ${ }^{26}$ especially in the wake of The Dismissal when he increasingly embraced the role of a pro-Labor intellectual and publicist. His political repositioning is important in the context of the present study.

Humphrey McQueen, a radical historian whom Clark had appointed senior tutor in his department, wondered how someone so mild-mannered could arouse such ire. ${ }^{27}$ It was the content of Clark's messages rather than his dulcet tones that was the provocation. The hostile response from the political right was heightened, precisely because the conservatives had no comparable 'guru' (or 'cultural statesman', if you prefer). Clark was

22 Manning Clark, The Quest for Grace, Ringwood: Penguin, 1991, p. 178. Yet on p. 204 he bemoans being relieved of teaching a course to diplomatic cadets in the Department of External Affairs, in which ASIO played a part, although he found this uninspiring work.

23 Fiona Capp, Writers Defiled: Security Surveillance of Australian Authors and Intellectuals, 19201960, Melbourne: McPhee Gribble, 1993, pp. 95-101; Roger Douglas, 'Brian Fitzpatrick, Manning Clark and ASIO', in Macintyre and Fitzpatrick, Against the Grain, pp. 170-90; Matthews, Manning Clark, p. 137; McKenna, An Eye for Eternity, pp. 394-95.

24 Jude van Konkelenberg, 'Australia's Cold War University: The Relationship between the Australian National University's Research School of Pacific Studies and the Federal Government, 1946-1975', PhD thesis, University of Adelaide, 2009, available at: digital.library.adelaide.edu.au/ dspace/handle/2440/63714; Geoffrey Gray, "'A great deal of mischief can be done”: Peter Worsley, the Australian National University, the Cold War and Academic Freedom, 1952-1954', Journal of the Royal Australian Historical Society, vol. 101, no. 1, 2015, pp. 25-44; Anderson, An Historian's Life, pp. 234-40. 25 Peter Ryan, 'Hollow Man of Yesterday', review of Manning Clark: A Life, by Brian Matthews, Quadrant, vol. 53, nos 1-2, January-February 2009, pp. 127-28, specifically p. 128.

26 Stephen Foster and Margaret M. Varghese, The Making of The Australian National University, 1946-1996, Sydney: Allen \& Unwin, 1996, p. 288.

27 Humphrey McQueen, Suspect History: Manning Clark and the Future of Australia's Past, Adelaide: Wakefield Press, 1997, p. 124. 
so much identified with the left's cultural dominance, and (incorrectly) seen by many as the evil genius behind Prime Minister Paul Keating's push for republican nationalism in the early 1990s, that he had to be brought down to discredit the cause he espoused (discussed in Chapter 7). As Macquarie University historian Portia Robinson pointed out, there were correlations between Clark's perceived influence and the abuse that his ghost had continued to encounter-hardly a novel proposition but apposite in the circumstances. ${ }^{28}$

Peter Ryan came from a different background. Born and brought up in Melbourne his childhood was not altogether happy. His schooling was marred by undiagnosed near-sightedness, and his consequent ineptitude at cricket and football ('I could scarcely see a ball before it hit me') resulted in an abiding distaste for sport of any kind, or so he said. ${ }^{29}$ As with Manning Clark, Ryan's description of childhood events is a forewarning of an unreliability with mere facts. Rather, he was a strong swimmer and was in his school's top football team. ${ }^{30}$ His father died when he was 13 , leaving him with a 'lasting sadness' that contributed to a grim outlook on life. Leaving school at age 16, Ryan was successively a clerk within the Commonwealth Railways and the Crown Law Office; the latter position, as his biographer notes, 'was a step closer to his ambition to become a lawyer' ${ }^{31} \mathrm{He}$ then, in 1941, enlisted for military service and served with distinction behind enemy lines in intelligence-gathering operations in the Papua New Guinea theatre. His wartime memoir, Fear Drive My Feet, is rightly regarded as a classic as well as being testimony to an enduring affection for the place and its people. ${ }^{32}$

Ryan took pride in his war record and his Military Medal and, not least, being part of the remarkable Directorate of Research and Civil Affairs (DORCA), which he joined in 1944. DORCA was one-of-a-kind. It was a shadowy, mysterious and raffish think tank within the Australian Army that was involved in what might be described as 'special duties of a secret

28 Portia Robinson, 'The abuse continues' (letter), Sydney Morning Herald, 3 September 1993, p. 10. Clark had been supportive of Robinson when her book, The Women of Botany Bay (1988), came under attack.

29 Peter Ryan, 'Short Sight, Sharp Vision' (1971), in his Lines of Fire, pp. 51-55.

30 John Tidey, Ryan's Luck: A Life of Peter Ryan MM, Melbourne: Arcadia, 2020, p. 7.

31 Tidey, Ryan's Luck, p. 11.

32 Peter Ryan, Fear Drive My Feet, Sydney: Angus \& Robertson, 1959. 
nature' concerning policymaking for the war effort and for postwar reconstruction. ${ }^{33}$ Ryan's two years in DORCA were a pivotal part of his life-he was a young man elevated beyond his wildest dreams and mixing with an intellectual elite who saw a new future for postwar Australia-but the fact remains that Ryan was a minor figure in the scheme of things. He looked back on DORCA with a lifelong affection and he lived long enough to bask in its glory. He wrote himself into the record with his writings on DORCA and subsequent researchers came knocking on his door for information about the outfit. He was a source of detail and anecdotes but not an historical actor of any significance. ${ }^{34}$

Ryan's literary background indeed had substance. He had received every encouragement as a child to read good books, and at high school he had, in the words of his English teacher, displayed 'a marked gift for literary expression', which carried over into adult life. ${ }^{35}$ The book-lined shelves in his home bear testimony to his literary interests and he spoke unaffectedly of his 'love of books and reading, which every year becomes a more consuming passion and which, like Gibbon, I would not exchange for all the treasures of India'. ${ }^{36}$ Ryan not only loved books but was a highly accomplished writer with a feel for language. And he valued his literary associations, which started with being an eager onlooker when two of his comrades at DORCA perpetrated the Ern Malley literary hoax-whereby the literato Max Harris (1921-1995), who championed modernist poetry, was fooled into publishing the nonsense poetry of a fictitious dead poet that the two hoaxsters had concocted during the course of an afternoon, thus achieving their twin objectives that modernist poetry and its sponsor be held up to ridicule. ${ }^{37}$ His literary crowd included Cyril Pearl

33 Graeme Sligo, The Backroom Boys: Alf Conlon and Army's Directorate of Research and Civil Affairs, 1942-46, Sydney: Big Sky Publishing, 2012.

34 Almost all the numerous references to Ryan in Sligo, The Backroom Boys, pertain not to what he did, which was to provide instruction in Pidgin, but to his recollections of DORCA. See also Ian Howie-Willis, A Medical Emergency: Major-General 'Ginger' Burston and the Army Medical Service in World War II, Sydney: Blue Sky Publishing, 2012, pp. 396-97. Ryan's various writings on DORCA include: 'Alf Conlon', in John Thompson (ed.), Five to Remember, Melbourne: Landsdown Press, 1964, pp. 113-15; 'Conlon, Alfred Austin (Alf) (1908-1961)', Australian Dictionary of Biography, The Australian National University, available at: adb.anu.edu.au/biography/conlon-alfred-austinalf-9804, published first in hardcopy 1993; and Brief Lives, Sydney: Duffy \& Snellgrove, 2004, pp. 28-61 (Alf Conlon), 139-52 (Ida Leeson).

35 Tidey, Ryan's Luck, p. 8, for quotation see p. 10, also pp. 123-26.

36 Ryan, 'Short Sight, Sharp Vision', in his Lines of Fire, for quotation see p. 54, also pp. 98-101.

37 Michael Heyward, The Ern Malley Affair, Brisbane: University of Queensland Press, 1993; Cassandra Pybus, The Devil and James McAuley, Brisbane: University of Queensland Press, 1999, pp. 39-44. 
(1904-1987), Paul Hasluck (1905-1993) and A.D. Hope (1907-2000); he also placed importance on rubbing shoulders with luminaries such as political scientist W. Macmahon Ball (1901-1986) and the renowned virologist Macfarlane Burnet (1901-1986). ${ }^{38}$ But the combination of knockabout, self-made man and literato is only half the picture. He also liked to present himself as a gentleman of the old school with extended lunches, his rural property and communion with nature, horse riding and, endearingly, when he became director of MUP, successive border collies curled up in front of his office fireplace. ${ }^{39}$

But that is well in the future. After being demobbed, Ryan enrolled at the University of Melbourne on a Commonwealth Reconstruction Training Scheme scholarship; he studied law in his first year and then switched to history, where he first encountered Manning Clark. ${ }^{40} \mathrm{He}$ was active in student politics as an office-bearing member of the university's Labour $\mathrm{Club}^{41}$ as well as standing for the Victorian State Parliament. Finishing his studies with an honours degree in history, he embarked on a series of jobs including

public servant $\ldots$ bush timberworker; publisher of comic books and other rubbish; ten years in advertising and public relations; and a hopeless effort to scratch a living as a freelance journalist. ${ }^{42}$

Then, in 1962, he unexpectedly became director of MUP upon the recommendation of Macmahon Ball, the professor of political science at the University of Melbourne and chair of the MUP Board of Management. It came about when Creighton Burns (1925-2008), a senior lecturer in Ball's department, casually suggested that Ryan was his man. ${ }^{43}$ Given Ryan's background in advertising and public relations, it was a surprise appointment. It was also an inspired decision to the extent that Ryan's

38 Ryan, Brief Lives, pp. 5-23 (Pearl), 62-73 (Burnet), 91-104 (Hasluck), 116-32 (Ball), 158-85 (Hope); and Lines of Fire, pp. 129-37 (Hasluck), 141-76 (Ball).

39 Peter Ryan, 'The Art and Craft of the Luncheon', Quadrant, vol. 52, nos 1-2, January-February 2008, pp. 127-28; Ryan, 'Winter Firewood' (1988), in his Lines of Fire, pp. 236-55; Ryan, 'Animals and Us', Quadrant, vol. 50, no. 3, March 2006, pp. 95-96; Ryan, Final Proof: Memoirs of a Publisher, Sydney: Quadrant Books, 2010, pp. 142-45, 194-95; Rowan Callick, 'A literary man of action' (obituary), Australian, 17 December 2015, p. 11, available at: oa.anu.edu.au/obituary/ryan-peter-25437.

40 Tidey, Ryan's Luck, pp. 43, 97.

41 John McLaren, Free Radicals of the Left in Postwar Melbourne, Melbourne: Australian Scholarly Publishing, 2003, pp. 60-61; Peter Ryan, 'End of the Dreamtime' (1986), in his Lines of Fire, pp. 101-11, specifically p. 106.

42 Ryan, 'My Life as a Leper', Quadrant, vol. 55, nos 1-2, January-February 2011, pp. 127-28, for quotation see p. 127; Tidey Ryan's Luck, pp. 46-53.

43 Tidey, Ryan's Luck, p. 63. 
good management was instrumental in clearing the press's debilitating overdraft and in maintaining a list of considerable merit. A long-serving chair of the MUP Board acknowledged:

how economically the Director and a handful of trusted colleagues managed the organisation, how meticulously he briefed the Board and its various committees, and how shrewdly he negotiated legal agreements. ${ }^{44}$

At MUP, Ryan joined forces with Manning Clark once again and got Volume 1 of the History into the bookshops in 1962, to the betterment of both MUP's and Clark's finances. They had much in common but eventually drifted apart. Clark was not an easy author, and he tested Ryan's patience. Their politics increasingly diverged with Ryan's swing to the right in the 1970s. Neither did Clark's tragic vision of Australian history nor the fluctuating quality of his work appeal to Ryan, although Ryan was exaggeratedly vocal in publicly praising both Clark as a great writer and his History as a great work. Another anomaly was Ryan's growing prejudice against academics generally, despite his working in a university setting for 25 years, or perhaps because of it. As a mutual friend lamented to Clark:

He is a remarkable person, in many respects admirable, but I wish he would not feed the already brightly blazing fire of Aussie antiintellectualism by constantly selling his own colleagues (for he is an academic too) down the river by describing them (in his excellent $\&$ most readable prose) as lazy layabouts. ${ }^{45}$

Thus, a good part of the equation is that two men who had been close, or close enough, had moved in different directions. Strangely, Clark seemed unaware of Ryan's change in political outlook, or the fact that Ryan was the proud custodian of a portrait of Sir John Kerr (1914-91), his former colleague at DORCA and later widely reviled for his role in The Dismissal of the Whitlam government in $1975 .{ }^{46}$ As late as 1987 , Clark told Ryan:

44 John Poynter, 'Peter Ryan the Publisher', Quadrant, vol. 60, no. 3, March 2016, pp. 58-59, specifically p. 59.

45 Susan Davies (ed.), Dear Kathleen, Dear Manning: The Correspondence of Manning Clark and Kathleen Fitzpatrick, 1949-1990, Melbourne: MUP, 1996, p. 112 (Fitzpatrick to Clark, 25 June 1987). 46 Ryan, Final Proof, pp. 195-97; Tidey, Ryan's Luck, pp. 98-99; see also Jenny Hocking, The Palace Letters: The Queen, the Governor-General and the Plot to Dismiss Gough Whitlam, Melbourne: Scribe Publications, 2020. 
[Paul Keating] is one of the most impressive men I have ever met in my life ... You would enjoy a talk with him. You would understand what he thinks about Australia and how he feels about life. ${ }^{47}$

A more improbable mismatch could hardly be imagined. Indeed, the increasing polarisation of Australian public life with an intensification of the History Wars in the lead-up to the bicentenary celebrations was an important element. It all came together with the sensational attack on Clark in the September 1993 issue of Quadrant.

47 Roslyn Russell (ed.), Ever, Manning: Selected Letters of Manning Clark, 1938-1991, Sydney: Allen \& Unwin, 2008, p. 451 (Clark to Ryan, 30 January 1987). 
This text is taken from History Wars: The Peter Ryan-Manning Clark Controversy, by Doug Munro, published 2021 by ANU Press, The Australian National University, Canberra, Australia.

doi.org/10.22459/HW.2021.01 